\title{
THE NEGOTIATING STRATEGY OF UNCLOS III: DEVELOPING AND DEVELOPED COUNTRIES AS PARTNERS-A PATTERN FOR FUTURE MULTILATERAL INTERNATIONAL CONFERENCES?
}

\author{
Alan Beesley* \\ I \\ INTRODUCTION
}

It is not clear from the little I have heard of the discussions thus far that there is general agreement that anyone who has made a contribution to the Law of the Sea Conference would be regarded as having made a positive contribution to peace, security, and the rule of law. In that event, you will be hearing a minority point of view from me because my government considers-and I agree-that the Conference was a smashing success. We regret that the U.S. Government does not see things in the same way.

It needs to be explained in brief what Conference I am talking about because we all seem to be talking about different conferences; indeed we seem to be talking about different Conventions according to our respective perceptions of this Convention. I therefore take the liberty of citing some high-level Canadian sources, and then I will plunge into the subject matter of my discussion, namely the negotiating process and its possible applicability to other conferences.

I want to begin by recalling that when the conference began, the law of the sea was in a state of disorder bordering on chaos. I am thinking more of 1967 than 1973, but there had not been much improvement in the meantime. There were conflicting claims on the breadth of territorial sea, the nature and extent of coastal jurisdiction over fisheries, the regime for marine scientific research, coastal state rights and obligations concerning the preservation of the environment, disputes as to the outer edge of the continental shelf, disagreements concerning the rule for boundary delimitation, and even whether or not there existed an international seabed beyond national jurisdiction. It was not so long ago that two NATO allies of the United States and Canada (the United Kingdom and Iceland) were in a confrontation over fishing rights, while later, two others (Greece and Turkey) engaged in a dispute in the Aegean over seabed limits and delimitation issues.

\footnotetext{
Copyright (C 1983 by Law and Contemporary Problems

* Ambassador of Canada to the Third United Nations Conference on the Law of the Sea: Chairman of the Drafting Committee of the Conference.
} 
Only a decade ago, Canada and the United States were in sharp disagreement concerning the environmental rights of coastal states in arctic waters. I mention this so that we can recall that the law of the sea is not just an academic issue for diplomats, lawyers, teachers, and students to consider in isolation from daily events. If we have disagreement about the rules of law governing the oceans, then we are going to have disputes. I think it is absolutely inevitable.

I would like also, before I discuss the negotiating process, to give you a kind of "birdseye" view of the Canadian perception of the results. To do so, I will quote very briefly from a statement by Dr. Mark MacGuigan, who was, until September of 1982, Canada's Secretary of State for External Affairs:

\begin{abstract}
A major contribution has just been made to the international rule of law by the third United Nations Conference on the Law of the Sea. The Conference is not merely an attempt to codify technical rules of law. It is a resource conference; it is a food conference; it is an environmental conference; it is a marine science conference; it is an energy conference; it is a conservation conference; it is an economic conference; it is a maritimeboundary-delimitation conference; it is a territorial limitation and jurisdictional conference; it is a transportation, communications, and freedom of navigation conference. It is a conference which regulates all the uses of the oceans by humanity. Most importantly, it is a conference which provides for the peaceful settlement of disputes concerning the oceans. It is, in other words, a conference dedicated to the rule of law among nations.
\end{abstract}

Now whether or not everyone here agrees that the Conference succeeded in all these areas, this is how it was seen from north of the border. I would like to stress the element of the peaceful settlement of disputes because it may be that the processes for peaceful settlement of disputes are not open to nonparties. I do not think that is a settled question. It is one I hope people will look into seriously.

Canada's Foreign Minister went on to say that he attached the highest importance to the impact which the Conference's success (because he saw the Conference as a success) may have in strengthening the role of the United Nations in finding viable solutions to great global issues. ${ }^{2}$ He further stated that the Third United Nations Conference on the Law of the Sea (in contrast to some of the statements we have heard) ranks in importance with the San Francisco Conference founding the United Nations itself. ${ }^{3}$ He said also:

It represents an extremely important element in the North/South dialogue. It has significant implications for peaceful East/West relations. It touches on the interests of every state, great or small, rich or poor, coastal or landlocked. The achievement of a universal agreement on a law of the sea convention is fundamental to world peace and security. ${ }^{4}$

We do not quite have universal agreement on a global convention. That was the objective. We came close, and I am still one of those who hopes that the efforts for consensus have not been entirely exhausted. I doubt that I will have time to go very deeply into that point, but there are still some efforts being made to leave the way open to ameliorate the situation with respect to the position of some countries.

1. Address by Dr. Mark MacGuigan, the Secretary of State for External Affairs of Canada, 36th Regular Session of United Nations General Assembly (Sept. 21, 1981).

2. Id.

3. Id

4. Id. 


\section{Negotiating StRategy}

I will now address the question of how the Convention emerged from the negotiations that occurred. What did our collective negotiating strategy have to do with it? What is the relationship between the way we all worked and what we achieved? The Conference was unusual in a number of respects. We have heard about some of the background, and I think it is relevant. We know about the Pardo initiative, and interestingly, I had always seen it in much the same light as it has been explained by Dr. Pardo 5 not merely as a thrust from the developing world for resources, but as an attempt to try to put some constraints on coastal states, particularly coastal states interested in extending their jurisdiction unilaterally.

Dr. Pardo has also referred to the Soviet Union initiative, ${ }^{6}$ and I personally received the document that they were presenting to certain countries. It was an attempt to reach an agreement on a twelve-mile territorial sea coupled with a high seas corridor. That very quickly became a joint USSR/USA initiative which included fisheries. We were amongst those who suggested that. Interestingly, it also included binding, third party settlement of fishery disputes.

Those initiatives, the Pardo initiative in particular, gave birth to the Seabed Committee, which soon began to take on a life of its own. The other pressures, interests and concerns, certainly those of the major maritime powers, had not been laid to rest by that initiative. More was needed than a regime for deep ocean space.

These separate strands met in 1970 when we passed two significant resolutions. One is often referred to-The Declaration of Principles Applicable to the Seabed Beyond National Jurisdiction. The other, however, was also important: the resolution agreeing to hold a Third United Nations Conference. I had the honor of chairing the informal negotiations leading to agreement on that resolution, and I introduced it into the first Committee of the United Nations.

We have heard something about the background to that decision. In brief, the major powers wanted a conference confined to a "manageable package" of issues. The developing countries, as well as some developed countries such as Canada and Norway, considered this to be only a piecemeal approach. They felt that there could be no resolution of some of the law of the sea issues without resolution of all of them because the issues were so interrelated. This led not only to the wider agenda - a very broad agenda-but also to the whole concept of the package deal; this concept was fundamental to the Conference from its outset, going back to the days of its Preparatory Committee, which began in 1970, when the Seabed Committee became the Preparatory Committee for a much more comprehensive Conference. The Seabed Committee became a much broader Committee. It had three Subcommittees within it in order to become a Preparatory Committee for the Conference. Already we had begun to develop some of the negotiating tech-

5. See Pardo, Before and After, LaW \& ConTemP. Probs., Spring, 1983, at 95, 96-97.

6. See id. at 95-96. 
niques which we gradually refined. It is important to remember how it all began. It began out of chaos and the widespread recognition that something had to be done about it. Obviously, I am one of those who hopes that we are not now about to return to that state of chaos because of the difficulty of reaching agreement on the present state of customary law and, therefore, on the implications of remaining outside the Convention.

Returning to the underlying basis of the negotiations, it became apparent that together with the package deal, the agreement on the consensus process was absolutely essential to the undertaking. This has been attempted in other major decisionmaking efforts within the United Nations: for example, the global negotiations, most of the disarmament discussions, and certainly UNCLOS I and UNCLOS II. It reflects a growing sophistication, I think, within the United Nations, an awareness that agreements that are reached by the simple process of voting through a majority view do not last. Such decisions do not really turn out to be agreements; they turn out to be a reflection of a point of view of the majority. If anyone is really attempting to build something that lasts, certainly something as important as a lawmaking instrument, it is now widely recognized that one should proceed by consensus. Of course, I am aware that many Americans are as concerned about the damage done to the consensus process (by the U.S. insistence on a vote, followed by its negative vote) as they are about the treaty itself. That is another reason why some of us are still working towards the possibility of one day arriving at a consensus. I am deeply aware, and Tommy Koh would be the first to remind me, that the Conference is over; but the process is not over.

Against this background of the package deal and the consensus principle, additionally we had widespread agreement from the outset that we were not about to develop one, two, three, four, or five conventions. There would be one integrated Convention since we did not want to make it possible, ironically enough, for states to opt into those parts of the Convention they liked while opting out of those they did not like. Canada did just that after the 1958 Conference. We ratified the one we liked, namely, the Continental Shelf Convention. We did not ratify the others because we intended to alter them and do things that might be considered incompatible with some of them. We wanted to prevent such a result this time, and eventually we did reach agreement in the closing days that there could be no reservations.

How then did the Conference work? Remember it did work! Interestingly, the beginning of the process was the creation of interest groups, which one might have thought would lead to clashes of views, sharp divergencies, and no progress. The opposite occurred. I think the first established was probably the coastal group, the most interesting characteristic of which was that it was composed of developed and developing countries (indeed, more developing than developed), thus marking the beginning of the partnership process.

That group, by its creation and by the dynamics of the process it set in train, had a constructive spinoff effect. Other groups were formed, not necessarily to oppose it, but in order to protect their respective interests and not just leave it as a coastal state conference. The maritime group formed. The major maritime 
powers began to meet together. That was later extended to a flag-state group for certain issues related, for example, to those touched on by Ambassador Vallarta. ${ }^{7}$ Also, it is fair to say that creation of the coastal group led directly to the creation of another very important interest group called the "landlocked and geographically disadvantaged group." For a long time the two used to play a game of singing out the numbers at various times to see who was outnumbering the other, not with a view to expecting to force through a vote, but with just the opposite view-to let each other know that each had a blocking third and to say, in effect, "Let's negotiate." The process was not an attempt to force a view down anyone's throat. Already, then, these two groups were joining issues. Interestingly, during this period states were beginning to determine not only where their interests lay, with whom they should be allied and where the opposition arose, but also how to work together as developed and developing countries within these groups. It is indicative that the landlocked and geographically disadvantaged group was also comprised of both developed and developing countries, as well as both Eastern and Western countries.

Meanwhile, of course, the Group of 77 already existed, and it was attempting to develop common positions where it could, particularly on the one issue that lent itself to a group approach, namely, the seabed beyond national jurisdiction. If it proved possible on that issue, it was rarely possible on much else. I think the Group of 77 was wise enough to know that. They did not have a uniform view, for example, on the 200-mile limit, or even on the 12-mile territorial sea, or on the rights of the landlocked. They could and did take a common position on the issues raised by what had started out as a mere concept or long-term objective, the "common heritage of mankind." Soon it was in the process of being translated from a concept into specific legal principles and, ultimately, into rules of law in treaty form. ${ }^{8}$

Meanwhile, there were also regional groups; these were more effective than the Western group within the Eastern European context, for example, and within the Group of 77. Meetings of the Western European and Others Group were notable mainly for the variety of views expressed on almost every subject. I recall Canada at times being odd-man-out on certain issues because of our environmental policies, our desire to extend our jurisdiction, our desire to do all the things we are accused of, creeping jurisdiction and all the rest, but we had some friends and allies in the group such as Norway, Iceland, Australia, and New Zealand. The Western European and Others Group soon found that it could work best by not working too closely together.

There were still other important East/West groups. The most interesting, I always thought, was the Group of Five, which I once mistakenly called the Gang of Five in a slip of the tongue, and of course the name stuck because this group

7. See Vallarta, Protection and Preservation of the Marine Environment and Marine Scientifuc Research at the Third United Nations Conference on the Law of the Sea, LAw \& CONTEMP. PROBS., Spring, 1983, at 147.

8. I am one of those who believe that we have gone a very long way in that process of giving specific legal content and status to the concept of the common heritage of mankind, but I will not argue that point here. 
included the United States and the Soviet Union as the backbone of the alliance, plus the United Kingdom, France, and Japan. I never understood why the Federal Republic of Germany was not included in that group.

The Group of Five was a very effective group. I remember trying hard, for instance, to ensure that the United States was given a fair hearing on marine science research even though it seemed clear that it was not going to get anywhere. Then, in between sessions, apparently there had been some bilateral talks resulting in a common USA/USSR position on marine science research, and from that point on it was a matter of trying to rescue something for the coastal states. If things turned out satisfactorily for the United States on that issue, it was due in part to the Gang of Five and their influence on the Conference process.

Other interest groups formed, some not as altruistic as the Group of Five. The environmentalists, for example, formed a group and were quite a coherent group from time to time. As Norm Wulf was saying, they began with a zonal approach, and then they dispersed into a variety of approaches and ended up working out what most regard as a fair accommodation of interests with the flag states and with one another. Once again, the environmental group, which Canada originally brought together, included both developed and developing countries working as "partners."

The territorialists, meanwhile, had come together. As far as I know, no developed country was ever a member of that group. It was a tightly knit group, and it had lost some of its impetus, I think, even though it used to continue to meet, until the consensus broke down. They seem to have had a new breath of life ever since, and I am worried about the consequences. I have seen a draft declaration that they might make in Jamaica, and all those who are sanguine about being able to go it alone and stick to the rules that they like, whether it is an appropriate course of action or not, should take into account the reactions that are already occurring as a consequence of the breakdown of consensus. I hope the territorialists do not desert the compromise that we worked out. It was so difficult to achieve, so bitterly fought, so carefully constructed. But the fact is that there is such a group of the territorialists; far from being stubborn, they simply represent countries which have not only made public commitments but which have fought a stiff battle over the years engaging their national pride, and, in their view, their national interests.

We had other interest groups. On boundary limitations we had one group, including both developed and developing countries, which favored the equidistance principle; another group, also including both developed and developing countries, favored equitable principles. I always thought they were the same thing, mind you, since equidistance is the most equitable approach, but not everyone agreed with that, and someone had to bring them together. So regularly we had this kind of arrangement within the Conference framework-negotiating groups under chairmen, picked, as was Ambassador Vallarta, for example, for their personal qualities. He presided over those primarily concerned with the environmental question. He had to bring together the environmentalists and the flag states and the major maritime powers, and I suppose he had to deal with the Gang of Five. 
As our methods evolved, we attempted to set up ad hoc working groups to bring together the major protagonists and attempt to settle one issue at a time, always having in mind the interrelationship of all the issues, so that all agreements were contingent. Of course each time we met, we would settle one, two, three, or five issues, and each time the press would report the Conference had failed again, whereas those of us involved in it were quite aware that we had made a significant amount of progress while still a long way from the end.

Not long after the beginning of the whole arrangement the archipelagic group formed and a straits group formed, and the two merged at times and separated at times, but they had a very important impact on the Conference. I cannot remember who took the initiative (allegedly it was Canada) when the land-based producers at some stage became an interest group, again made up of both developed and developing countries, and they were quite a tightly knit group for a while, and then they were not, and then they were again. They actually delegated some of their powers to one member of the group to deal with the major protagonists on the other side, and that is how it came to be that the United States and Canada sat down to hammer out the first part of that famous nickel production formula that has since been disowned by so many people.

The "margineers" (the name given to those states, both developed and developing, which, as they perceived things, had very broad continental shelves) wanted to protect their interests, so they met together. But meeting together and preaching to the converted did not achieve much; they had to sit down with others who disagreed with them. They had to do this either within ad hoc working groups or within the general process of the committee debates.

By this time we had not only set up the three separate committees, as in the Seabed Committee, but also we had carried them forward into the Conferencefrom the time it began. We had Committee One, concerned with the seabed regime and the institutions to be created. (How can you create an institution by customary law? I suppose by getting enough states to agree to it. In any event, that was Committee One's mandate.) Committee Two had most of the fundamental jurisdictional issues, and in the minds of most of us, they were amongst the most difficult and intractable problems of all. Committee Three dealt primarily with the preservation of the marine environment, marine scientific research, and the transfer of technology. This scope was narrowed to cover only the transfer of marine technology because meanwhile the same important issue was being fought out in Committee One on the seabed.

Another interest group was the semi-enclosed sea group. Unlike the other groups, this group was regrettably unfamiliar to me because I never had the opportunity to become directly involved in their activities. I had many occasions to meet with one or more of these other groups.

Eventually, by the closing days, we also had a kind of loosely knit group called the Pioneer Seabed Miners. I do not know whether they ever met as a group, but they made it clear by the positions they took that they had a common interest. They were the states, actually named in Resolution II, Article 1(a)(ii) which gave 
the West (and some others, such as India and the U.S.S.R.) so much of what they had been demanding.

At the very end, in the last few weeks of the Conference, another interest group was formed. That was a very special group which did not have any common interest except the successful conclusion of a Convention. I do not mean to make it sound like an idealistic group; it was acting out of self-interest-an interest in a global treaty. However, it had diverse national interests. This was the group that came to be known as the Group of 12. Once again, it was called together by means of one of those Canadian working luncheons, which were very effective in terms of producing work. The Group of 12 was set up for one simple reason-to attempt to bridge the differences on the seabed regime, very evident by this time, between the United States (and some other major developed countries) and the Group of 77. The Group of 12 were all developed countries, the only interest group in which Canada participated which did not include developing countries. It consisted of countries such as Australia, New Zealand, Canada, the Nordics (including Denmark, Ireland, and the Netherlands, some Common Market countries), plus Austria and Switzerland-a fairly respectable group--not mentioned at all by people later analyzing who might sign and who might ratify. We heard about the great powers; we heard about the developing countries; we did not hear about this group.

Initially, the Group of 12 consisted of heads of delegations acting in their purely personal capacity. We were all interested in the Convention. We had all put a lot into it. We focused on the President's statement, his six principles. We did not attempt to translate into action the sixty-six pages of U.S. amendments; that was beyond our abilities, and we knew it. We concentrated on what we thought might be achievable. We worked very, very hard to get exactly that, right up to the closing hours of the last day. We failed, and we deeply regret it, but we still remain convinced that we were very near success, in spite of the differences.

The foregoing is just a quick run-through touching on some of the interest groups, and it may sound as if it is all neat, logical, and obvious when it is spelled out this way, but the process actually evolved gradually. It was not clear at all. Some countries belonged to a half dozen or more of these interest groups. Some did not even know at the beginning where their interests directed them. They found out as they went along. I remember at one time the delegation of Singapore was about to join the coastal group on instructions when someone suggested to them that it was the wrong group and that Singapore should join a different group (which later became known as the landlocked, geographically disadvantaged group). From then on Singapore and Canada were arguing with each other instead of working together in the same group, except in the collegium, something I will mention a little later.

We had all these interest groups, we had ad hoc working groups, and we had official negotiating groups set up within the conference system by the three Committees. In addition to all this - and I shall not even begin to describe the many working groups, ranging from the Group of 21 , the major negotiating group on the seabed regime, to the Vallarta environmental group I mentioned earlier, to the 
special group on peaceful settlements, to the delimitation group - we had various unofficial, informal groups, and that is where some of the best work was done. There was the Evenson group, as it was called, named after the Norwegian Ambassador, and the Castenada group, named after Jorge Castenada, Foreign Minister of Mexico. Several of the major Conference concepts were developed into agreed treaty language in the Evenson group and Castenada group. This might not have happened but for the existence of these informal groups.

So we used a variety of techniques, as you can see, but the one characteristic that marked most of these activities, although not quite all of them, is that the developed and developing countries did not sit down and assume they were enemies and therefore attempt to determine how they could defeat each other. Instead, there was a recognition that they might have something in common, that at least they should try to determine whether that was the case, and work together where they could. Where they could not, as seemed to be the case sometimes in the First Committee, there was tension, sometimes creative tension, but in any event, there was a need for real negotiation between groups. One should not forget that the developed countries were not all of one mind. At one stage Australia and Canada, as landbased producers, did not see entirely eye-to-eye with some of the other major developed countries who were consumers of the metals that are found in the seabed. We had to iron out differences within our own group, if you could call the WEOG (Western European and Others Group) a group. We usually were termed a group in statements, but we rarely acted as a group.

Where did this all lead? As an example of the results of this process, Ambassador Nandan of Fiji chaired a group that worked endlessly until it finally achieved agreement on the rules relating to the landlocked and geographical disadvantaged states. These are significant rules, new rules relating to rights of landlocked states. It is more than just old rules that he codified for this treaty from somewhere else. He had earlier been a co-chairman with a member of the British delegation that worked out the package on straits. We did not take a vote or make a formal decision to appoint such groups. It evolved. It happened. This was a mark of the Conference: much of the real work was done privately, behind the scenes, without records. It is an unfortunate development in one respect. We do not have a complete record of the conference negotiations. On the contrary, we have very incomplete records, but we might never have reached agreement if we had to speak for the record. All of these techniques were used in order to ensure that a conference so complex and many-sided was moving on a range of issues at one and the same time. For some of us it meant that we had to have roller skates to keep up with the various groups in which we were involved.

In addition to this process, we gave tremendous powers to the Collegium, particularly the President and the Chairmen of the three Committees. I do not know of a precedent for this. One can draw an analogy, perhaps, to the special Rapporteurs appointed for various subjects in the International Law Commission, but it is not really a felicitous analogy. We gave tremendous powers to the respective Chairmen, who were given a mandate to attempt to reflect in a concrete text what was called a "negotiating text"-not a "negotiated text"-from each session. We 
gradually consolidated this process and, perhaps, institutionalized and refined it by working as a Collegium to try to determine when a proposal before the Conference would constitute a further step towards consensus if it were included in our negotiating text.

This process involved the somewhat little known and mysterious dynamics of consultation within the Collegium, which was comprised of the President of the conference, formerly Shirley Amerasinghe, later Tommy Koh, plus the chairmen of the three substantive committees, Paul Engo of Cameroon, from Committee One, Andreas Aguilar of Venezuela, from Committee Two, and Alex Yankov of Bulgaria, from Committee Three, plus myself as Chairman of the Drafting Committee and Ken Nattray as Rapporteur General, together with the special representative of the Secretary-General sitting in a consulting capacity.

As Chairman of the Drafting Committee, I had the worst job in the Conference, but fortunately I also had the best kind of support for which anyone could have wished. I am mentioning this because we too evolved our own special negotiating methods, and they were unique. I do not know if they will be followed elsewhere. There are different views on that; we discovered that because of the package-deal concept, coupled with the consensus procedure, there was such nervousness about "putting to bed" any part of the package before the whole outline had been blocked out that the Drafting Committee had to wait in the wings for a very long time and attempt in the meantime to do useful technical work without coming to grips with the real drafting issues. We had already been stripped of any substantive powers, and we were told to confine ourselves to pure drafting points; so we worked on harmonization problems, trying to get the inconsistencies out of the text where the same terminology was used to mean different concepts or where different terminology was used to mean the same thing. Thus before we were permitted to begin our article-by-article analysis, it was necessary that the Conference go a very long way in settling the substantive issues.

As a consequence, in spite of my annual and semi-annual speeches to the Conference warning of what would happen, it did happen. We were suddenly told to do the whole job in a hurry. It proved a very difficult task indeed. We ended up making something between six thousand and seven thousand recommendations for changes, virtually all of which (over ninety-nine percent) were accepted. Hence, whatever is wrong with the text (and I do not agree with Arvid Pardo's criticism, although there may still be technical difficulties) I can say, having gone over every article, that the text is vastly improved from what it was.

We would not have been able to complete this task or even to make a good beginning without the creation of what we called "language groups," an odd term for an unusual mechanism. We found that because many parts of the texts had been translated overnight after weeks of negotiation, many problems resulted. For the negotiations that were in English, the other five official texts were often translated in a hurry, through no one's fault, particularly not the fault of the dedicated, hard working and efficient Secretary of the Drafting Committee. What we found we had to do was twofold: first, bring those who were not members of the Drafting Committee into the process, those many delegates who wished to make an input; 
and second, ensure that there was some consultative process, some working basis, whereby the Secretariat experts (experts in their own respective languages as well as experts on the subject matter) could work directly with delegations and attempt to resolve the difficulties presented by the text. So we established what we termed "language groups." We then had to invent a term for the leaders of language groups, so we called them "Coordinators."

Neither France, the United Kingdom, nor China was a member of the Drafting Committee, even though three of the official languages were French, English, and Chinese. By the device of these coordinating groups, we were able to hear from those who were not in the Drafting Committee, including two successive very distinguished Arab coordinators who did not happen to represent countries which were members of the Drafting Committee. We obtained their input and their expertise, and this process of give and take with the Secretariat developed eventually into a harmonious process. My job as Chairman was easiest, in that they, the language groups and the Secretariat, did much of the work. I had to ensure that the whole process worked smoothly, and that task was probably the most arduous of any I have ever performed in my life. I doubt that the Drafting Committee, and the Coordinators in particular, as well as the Secretariat experts, and the secretary of the committee most of all, will ever get the recognition they deserve.

The Drafting Committee was not engaged in negotiations, in the usual sense of the term, because it was not involved in negotiating substance. It was attempting to translate the existing informal texts reflecting substantive agreement into enforceable treaty language, for the purpose of producing an agreed treaty.

This has been a very brief, once-over-lightly explanation of some aspects of the negotiating power. If it sounds confusing, complex and sometimes obscure, even opaque, that is what it was. It was never easy, but it worked. Whether we all agree on the results, the Convention is nonetheless an almost unbelievable achievement, namely, that 157 states reached the measure of agreement that was reached, even though we came to a vote in the end. Certainly well over ninety-seven to ninety-eight percent of the articles of both the text and the annexes were negotiated by consensus. That is why I am half with, and half against, Professor Clingan and Admiral Harlow when they argue that we all participated in the negotiation of so many of these texts, by consensus, and we want to support them. ${ }^{9}$ We want to participate as a member of the international community in translating these treaty provisions into agreed rules of law, whether or not they have yet attained that status. My hope is for all concerned to realize how important it is for the United States to do the same with Part XI. In the meantime, we have the conundrum of the portion of nonparties concerning the status of the treaty concepts.

9. See Clingan, Freedom of Navigation in a Post-UNCLOS III Environment, LAW \& CONTEMP. PROBS., Spring, 1983, at 107; Harlow, Comment, Law \& CoNTEMP. Probs., Spring, 1983, at 125. 


\section{III}

\section{CONCLUSION}

In terms of lessons for the future, it seems clear that where the developed and developing countries worked together as partners, success was achieved. Where they worked together as antagonists, less success was achieved. It may be that the developed and the developing countries, and the East and the West, share more common interests than is generally recognized. In any event, that is my view; that is how we approached the law of the sea negotiations; and I hope Canada will approach other important negotiations, including those on disarmament, with the same attitude. 